\title{
Organoleptic Quality of Corn Flour (Zea mays I.) by Oven Method
}

\author{
Andi Abriana ${ }^{1 *}$, Andi Tenri Fitriyah ${ }^{1}$, Suriana Laga ${ }^{1}$, and Sumiati ${ }^{2}$ \\ ${ }^{1}$ Food Technology Department, Agriculture Faculty, University of Bosowa, Makassar, \\ Indonesia \\ ${ }^{2}$ Agricultural Economics and Management, Anhui Agricultural University, China
}

\begin{abstract}
Diversification of processed corn into flour increases corn value. Corn flour is a fine grain from dried corn. This study was carried out to determine the organoleptic quality of corn flour (texture, color, and aroma) through the drying process by the oven method. The best moisture test of dried corn flour was at $80^{\circ} \mathrm{C}$, with $7.5 \%$ of moisture content, and 3 hours of the drying process. The organoleptic test showed a different score of aroma, color, and texture at various temperatures. Based on panelist assessments showed that 3.71 of aroma score (rather like), 3.86 of color score (rather like), and 2.86 of texture (like moderately) at $60^{\circ} \mathrm{C} ; 3.71$ of aroma, color, and texture score (like) at $70^{\circ} \mathrm{C} ; 4.14$ of aroma score (like), 3.71 of color score (rather like), and 4.86 of texture score (like very much) at $80^{\circ} \mathrm{C}$. The best result from organoleptic evaluation test was corn flour by drying at $80^{\circ} \mathrm{C}$ with 4.24 of average score and included preferred category.
\end{abstract}

\section{Article History}

Received February 19, 2020

Accepted June 21, 2020

Keyword

Corn flour,

Organoleptic test,

Drying,

Oven method

\section{Introduction}

Corn (Zea mays L.) is a potential source of carbohydrates as flour and corn starch in Indonesia. It can be used as raw materials for new food products (1).

According to the Central Bureau of Statistics in 2016, corn production reached 19.6 million tons in 2016 and came in the third rank after rice (75.3 million tons), and cassava (19.6 million tons). Therefore, corn can be used as food diversification by processing corn into flour. Corn flour useful as food substitution.

Corn plays an important role in the food development and food industry due to its chemical composition and nutrient content. Therefore, it is vital for food and industrial raw materials (2). Corn needs for public consumption and the food industry are continuously increased. Corn flour is a potential for food diversification (3).

The use of corn as an industrial raw material increases the commodity value. Corn can be processed into corn flour, rice corn, snack, cooking oil, and margarine (4). Furthermore, corn can be processed into flour to diversify processed food.

Corn diversification increases corn value. Corn flour is used as the initial step for corn diversification. It has several advantages : (1) corn flour is widely used as a raw material in various kinds of food products; (2) easy storage; (3) the deficiency of nutrients can be enriched or supplemented; and (4) easy to mix with other materials (5).

Corn flour is a fine grain from dried corn. Processing corn into flour is recommended compared to other semi-finished products. It can be enriched in nutrition, easy to storage, mix, and use for further processing. Yellow corn and white corn can be processed into corn 
flour. Rough handling and non-hygienic during flour processing will decrease the quality of flour (6).

Drying is heating through normal conditions. It eliminates water in a material by evaporating (7). Drying can be performed by the oven method. It is a device for heating, baking, and drying. The oven can be used as a dryer with a combination of heating, low humidity, and sufficient air circulation. The drying speed depends on the material thickness. It is used for small scale. The electric oven consists of several trays inside and has air circulation. It can be adjusted and maintained.

Corn flour production is performed by the dry milling method. Milling is conducted twice. The first milling (rough grinding) is performed by a hammer mill. Thus, the corn grits obtained are washed and soaked in water for 3 hours. Soaking is performed to facilitate the grinding process. The second milling is performed by a fine grinder. The results of fine milling are corn flour and sifted with a 100 mesh. The biggest component in corn flour is starch, with $68.2 \%$ of starch content (6).

This study aims to determine the organoleptic quality of corn flour (texture, color, and aroma) by the oven drying process.

\section{Materials and Methods}

Peeling machines, milling machines, plastic buckets or basins, stainless steel containers, water, the size 60 mesh sieving or filter, and oven were used in this study. Yellow corn was obtained from corn farmers in North Luwu Regency.

\subsection{Research Procedure}

Best-dried corn was used in this study. Corn milling was conducted by a grinding machine to gain corn flour with a rough texture. Thus, soaking corn flour was conducted for 3 hours in water. Drying of corn flour was performed in an oven at $60^{\circ} \mathrm{C}, 70^{\circ} \mathrm{C}$, and $80^{\circ} \mathrm{C}$ for 3 hours. Sifting corn flour was conducted using a 30 mesh. The storage of corn flour was placed in a closed container and avoid sunlight.

\subsection{Research Analysis}

\subsubsection{Water content in dry basis}

Water content in dry basis analysis was repeated 3 times. Five-gram samples were put into a petri dish. The sample was dried at $100^{\circ} \mathrm{C}-105^{\circ} \mathrm{C}$ for 6 hours in an oven. Then, the sample was cooled in a desiccator and weighed. The difference in weight before and after drying was calculated (8).

$$
\text { Water content }=\frac{\text { initial weight }- \text { final weigh }}{\text { initial weight }} \times 100 \%
$$

\subsubsection{Organoleptic Test}

The organoleptic test on corn flour was conducted to determine flavor, color, and texture by panelists using a hedonic scoring scale (table 1) (9). 
Table 1. Test of Organoleptic scale.

\begin{tabular}{lc}
\hline Hedonic scale & Numeric Scale \\
\hline Like very much & 5 \\
Like & 4 \\
Like moderately & 3 \\
Dislike & 2 \\
Dislike very much & 1 \\
\hline
\end{tabular}

\subsection{Research Design}

The research design was a completely randomized design with three replications. Data were analyzed by SPSS and ANOVA. Duncan's test was conducted for further tests.

\section{Results and Discussion}

\subsection{Water Content}

The water content in food ingredients determines the acceptability, freshness, and durability of the material. Besides being a part of a food ingredient, water is a good washing agent for the foodstuff or the tools. The water content affects food resistance to microbial (10).

The water content in food needs to be known to determine the nutrients contained in the food. Water is essential in food. It is needed for the biochemical viability of living organisms. It is due to the water content that affects the texture, flavor, and color. Furthermore, it affects the durability of food from microbial (11).

The water content of corn flour is analyzed by drying. It is performed by evaporation in food through heating. Thus, weigh the material up to a constant weight. Therefore, all the water content is evaporated.

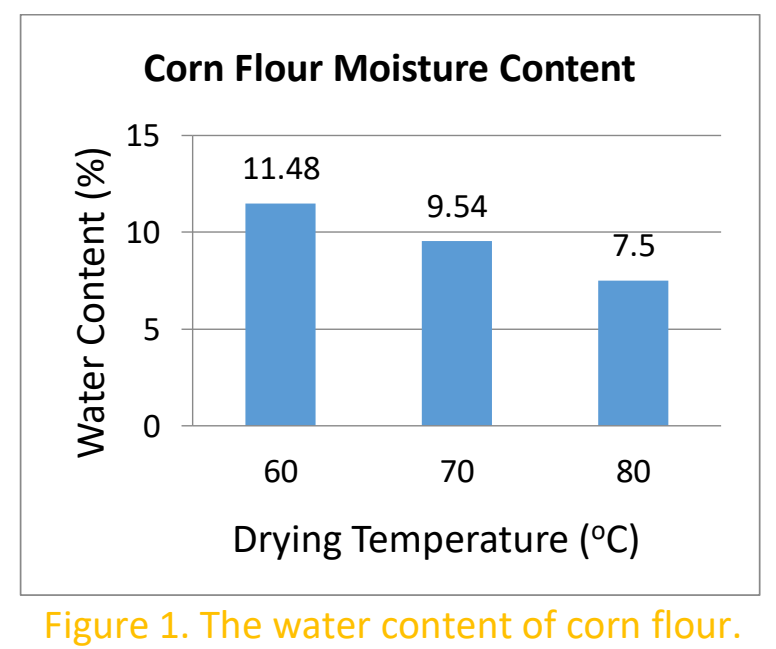

The highest water content is found in corn flour by drying at $60^{\circ} \mathrm{C}$ and the lowest at $80^{\circ} \mathrm{C}$. It indicates that decreasing water content following by increasing drying temperature. The higher the drying temperature, the lower the water content of corn flour. The water content of corn flour that dried at $70^{\circ} \mathrm{C}$ and $80^{\circ} \mathrm{C}$ were $9.54 \%$ and $7.5 \%$, respectively. Those indicated that the corn flour from this research meet the SNI requirements. According to SNI number 01-3727 (1995), the water content of corn flour was maximum 10\% (12). 
The water content of corn flour is 7.5 to $11.48 \%$. The water content of corn flour is lower than the results of Aini et al. (2016) (13). It is caused by different drying times and methods. Corn flour is dried by a cabinet dryer at $50^{\circ} \mathrm{C}$ for 3 hours (13), whereas in this study, the drying temperature was $60^{\circ} \mathrm{C}, 70^{\circ} \mathrm{C}$, and $80^{\circ} \mathrm{C}$ for 3 hours by oven drying method. The more extended drying temperatures decrease water content. Food must have low water content below $10 \%$. It can be stored for a long time (13). Corn flour has $9.54 \%$ of water content at $70^{\circ} \mathrm{C}$ and $7.5 \%$ at $80^{\circ} \mathrm{C}$. Therefore, it is expected to have a longer shelf life.

\subsection{Organoleptic Test \\ 3.2.1. Aroma}

Food aroma determines food delicacy and correlates with a smell. It recognizes food delicacy without tasting directly. In general, aroma received by smell (nose).

Yellow corn smell unpleasant. Therefore, if it mixed with processed foods such as dry noodles also smell unpleasant. It is due to yellow corn grinding contains high unsaturated fat (14).

Aroma score was 3.71 at $60^{\circ} \mathrm{C}$ and $70^{\circ} \mathrm{C}$ and categorized as rather like, while was 4.14 at $80^{\circ} \mathrm{C}$ and categorized as like according to the organoleptic test. It indicates that panelists more prefer corn flour at $80^{\circ} \mathrm{C}$ of drying temperature. This finding shows that the higher drying temperature produces the preferred aroma of corn flour (Figure 2).

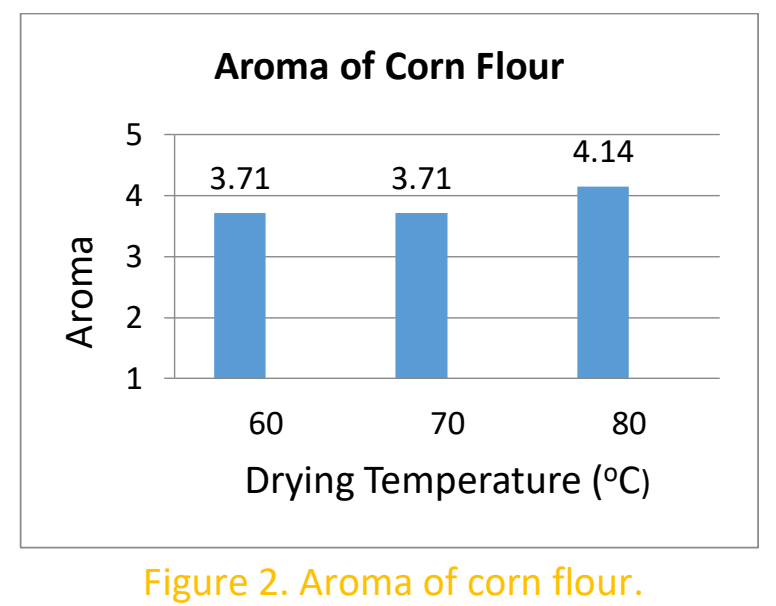

Sweetbread from corn flour within the dry and wet flouring method has a different aroma. It is due to corn flour by a dry method cannot remove much aroma, whereas the wet flouring method dissolves aroma from the sweet corn. Therefore, when it substitutes into sweet bread will reduce aroma from sweet corn (15).

F-value, F-table, and p-value were 1.778, 2.6, and 0.187, respectively, based on oven drying at $60^{\circ} \mathrm{C}, 70^{\circ} \mathrm{C}$, and $80^{\circ} \mathrm{C}$. In a present study, p-value was 0.187 and more significant than the alpha value (0.05). It indicates that corn flour aroma is not significant. Therefore, corn flour flavor did not have a positive contribution (table 2). 
Table 2. Test results of corn flour.

\begin{tabular}{|l|r|r|r|r|l|}
\hline Source & $\begin{array}{c}\text { Type III Sum } \\
\text { of Squares }\end{array}$ & Df & $\begin{array}{l}\text { Mean } \\
\text { Square }\end{array}$ & \multicolumn{1}{c|}{$\mathrm{F}$} & Sig. \\
\hline Corrected Model & $5.429^{\mathrm{a}}$ & 8 & .679 & 1.583 & .228 \\
Intercept & 312.429 & 1 & 312.429 & 729.00 & .000 \\
Flavour & 4.571 & 6 & .762 & 1.778 & .187 \\
Temperatue & .857 & 2 & .429 & 1.000 & .397 \\
Error & 5.143 & 12 & .429 & & \\
Total & 323.000 & 21 & & & \\
Corrected Total & 10.571 & 20 & & & \\
\hline
\end{tabular}

\subsection{Color}

Color is primarily considered by humans in selecting food. Food with high nutritional value, good tastes, and texture will not be chosen if it has unattractive color. Color is the vital preference test in determining whether a food will be consumed or not before other factors.

Color plays an important role in product selection. Unattractive colors reduce consumer preference for food products. Therefore, it is the quickest and easiest response in giving a good impression (16).

Corn flour produced by oven drying at different temperatures has a different average color preference. The average score was 3.16 at $60^{\circ} \mathrm{C}$, while it was 3.71 at $70^{\circ} \mathrm{C}$ and $80^{\circ} \mathrm{C}$ within rather like category. This finding reveals that the drying temperature does not affect the color of corn flour (figure 3 ).

In a present study, $F$ count $>F$ table $(3.125>2.6)$. It indicates that different temperature of drying does not affect the color. Furthermore, $p$-value $<(0.044<0.05)$. It reveals that the color produced by drying oven at $60^{\circ} \mathrm{C}, 70^{\circ} \mathrm{C}$, and $80^{\circ} \mathrm{C}$ is the preferred category based on panelist (table 3).

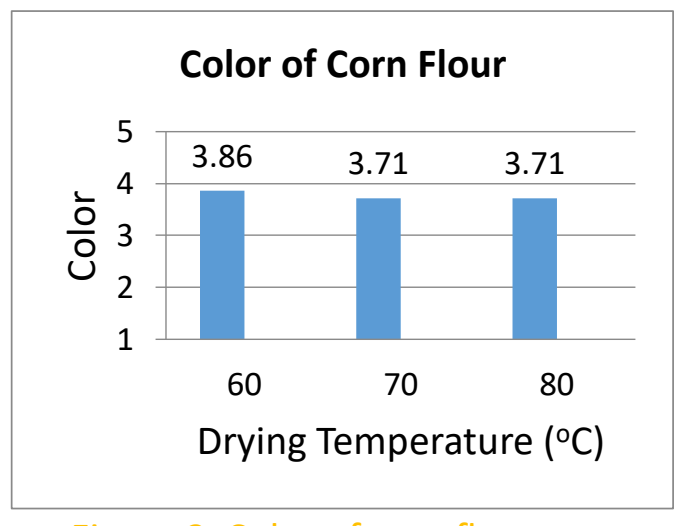

Figure 3. Color of corn flour.

Table 3. Color test of corn flour.
\begin{tabular}{|l|r|r|r|r|r|}
\hline Source & $\begin{array}{l}\text { Type III Sum } \\
\text { of Squares }\end{array}$ & Df & $\begin{array}{c}\text { Mean } \\
\text { Square }\end{array}$ & F & Sig. \\
\hline Corrected Model & $7.238^{\mathrm{a}}$ & 8 & .905 & 2.375 & .086 \\
Intercept & 297.190 & 1 & 297.190 & 780.125 & .000 \\
Colour & 7.143 & 6 & 1.190 & 3.125 & .044 \\
Temperature & .095 & 2 & .048 & .125 & .884 \\
Error & 4.571 & 12 & .381 & & \\
Total & 309.000 & 21 & & & \\
Corrected Total & 11.810 & 20 & & & \\
\hline
\end{tabular}




\subsection{Texture}

Texture is a very important trait, both in fresh food and processed products. Texture is one of the organoleptic factors that often changes during storage. Food texture testing is an attempt to find the right texture parameters that must be an attribute of the food quality.

Texture plays an important role in the selection of a product. It is caused by consumers want texture according to the product type there by increasing consumer acceptance of the product (16).

The texture of corn flour produced is smooth and does not feel any granules along with the increase in drying temperature. The higher the drying temperature, the finer corn flour will be produced, thereby increasing consumer acceptance of corn flour products.

The average preference of corn flour texture was 2.86 at $60^{\circ} \mathrm{C}$ and included as like moderately category; 3.71 at $70^{\circ} \mathrm{C}$ with the category rather like; and 4.86 at $80^{\circ} \mathrm{C}$ with like very much category (Figure 4).

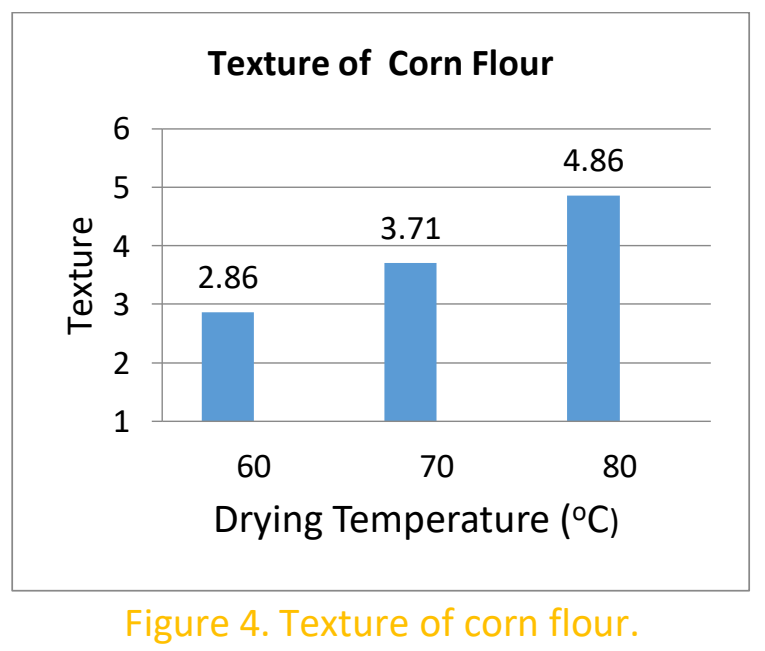

In a present study, $\mathrm{F}$ value $>\mathrm{p}$-value $(4.732>0.01)$ based on test of corn flour texture. It reveals that there is a significant effect on corn flour texture by drying process at $60^{\circ} \mathrm{C}, 70^{\circ} \mathrm{C}$, and $80^{\circ} \mathrm{C}$ (Table 4).

Table 4. Results of Corn flour texture.
\begin{tabular}{|l|r|r|r|r|r|}
\hline Source & $\begin{array}{l}\text { Type III Sum } \\
\text { of Squares }\end{array}$ & Df & $\begin{array}{c}\text { Mean } \\
\text { Square }\end{array}$ & F & Sig. \\
\hline Corrected & $23.333^{\mathrm{a}}$ & 8 & 2.917 & 8.963 & .000 \\
Model & 304.762 & 1 & 304.762 & 936.585 & .000 \\
Intercept & 9.238 & 6 & 1.540 & 4.732 & .011 \\
Texture & 14.095 & 2 & 7.048 & 21.659 & .000 \\
Temperature & 3.905 & 12 & .325 & & \\
Error & 332.000 & 21 & & & \\
Total & 27.238 & 20 & & & \\
Corrected Total & & & & & \\
\hline
\end{tabular}

The average homogeneous or equal group was texture in Experiment 2. Thus, experiment 1 located in the first subset. Experiments 1, 5, 6, and 7 located in the second subset. In addition, the third subset was in experiments $3,4,6$, and 7 . Drying process at $60^{\circ} \mathrm{C}$ located in the first subset, $70^{\circ} \mathrm{C}$ at the second subset, and $80^{\circ} \mathrm{C}$ at the third subset based on Duncan's test (table 5). 


\begin{tabular}{|c|c|c|c|c|}
\hline \multirow[t]{2}{*}{ Texture } & \multirow[t]{2}{*}{$\mathrm{N}$} & \multicolumn{3}{|c|}{ Subset } \\
\hline & & 1 & 2 & 3 \\
\hline $\begin{array}{l}\text { Experiment } \\
2 \\
\text { Experiment } 1 \\
\text { Experiment } 5 \\
\text { Experiment } 6 \\
\text { Experiment } 7 \\
\text { Experiment } 3 \\
\text { Experiment } 4 \\
\text { Sig. } \\
\end{array}$ & $\begin{array}{l}3 \\
3 \\
3 \\
3 \\
3 \\
3 \\
3\end{array}$ & $\begin{array}{l}2.6667 \\
3.0000\end{array}$ & $\begin{array}{l}3.0000 \\
4.0000 \\
4.0000 \\
4.0000\end{array}$ & $\begin{array}{r}4.0000 \\
4.0000 \\
4.0000 \\
4.3333 \\
4.6667 \\
.215\end{array}$ \\
\hline
\end{tabular}

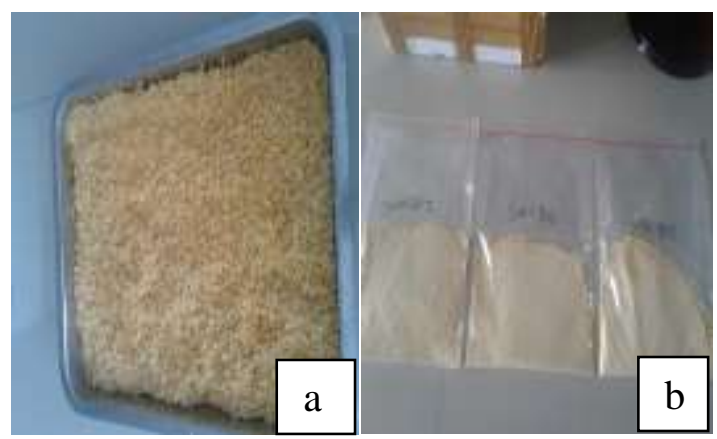

Figure 5. Coarse corn flour (a) and fine corn flour (b).

\section{Conclusions}

Drying at $80^{\circ} \mathrm{C}$ for 3 hours produced the best water content of corn flour. The flavor score was 3.71 (rather like), 3.86 of the color score (rather like), 2.86 of texture score (like moderately) at $60^{\circ} \mathrm{C}$. Thus, at $70^{\circ} \mathrm{C}$ produced 3.71 of aroma score (rather like), 3.71 of the color score (rather like), 3.71 of texture score (rather like). The aroma score was 4.14 (like), 3.71 of the color score (rather like), and 4.86 of texture score (like very much) at $80^{\circ} \mathrm{C}$. The best result from organoleptic evaluation test was corn flour by drying at $80^{\circ} \mathrm{C}$ with 4.24 of average score and included preferred category.

\section{References}

1. Saniati ND, Nurdjanah S, Musita N. Sifat Organoleptik Mie Berbahan Dasar Tepung Jagung (Zea mays L.) Ternikstamalisasi. J Teknol Ind Has Pertan. 2013;18(2):114-22.

2. Midlanda HM, Lubis LM, Lubis Z. Pengaruh Metode Pembuatan Tepung Jagung dan Perbandingan Tepung Jagung dan Tepung Beras terhadap Mutu Cookies. J Rekayasa Pangan dan Pertan. 2014;2(4):20-31.

3. Lombu WK, Wisaniyasa NW, Wiadnyani S. Perbedaan karakteristik kimia dan daya cerna pati tepung jagung dan tepung kecambah jagung. J ITEPA. 2018;7(1):43-53.

4. Budiman H. Sukses Bertanam Jagung Komoditas Yang Menjanjikan. Bandung: Bandung: Pustaka baru Press; 2010.

5. Marta H, Tensiska T. Kajian Sifat Fisikokimia Tepung Jagung Pragelatinisasi serta Aplikasinya pada Pembuatan Bubur Instan. JP2| J Penelit Pangan. 2016;1(1):14-21.

6. Juniawati. Optimasi Proses Pengolahan Mie Jagung Instan Berdasarkan Preferensi Konsumen. Institut Pertanian Bogor; 2003.

7. Muarif. Rancang Alat Pengering. Politeknik Negeri Sriwijaya Palembang; 2013. 
8. Ramadhani NF. Model Pengeringan Lapis Tipis Pada Cabai Merah Besar Varietas Tombok. Universitas Hasanuddin; 2011.

9. Gaspersz V. Teknik analisis dalam penelitian percobaan. Vol. 321, Tarsito. Bandung. Bandung: Penerbit Tarsito; 1995.

10. Abriana A. Analisis Pangan, Teori dan Metode. Makassar: CV. Sah Media; 2018.

11. Winarno FG. Kimia Pangan dan Gizi. Jakarta: PT Gramedia; 2004.

12. Nasional BS. Standar Nasional Indonesia. SNI 01-3727-1995 Tepung Jagung. Badan Standarisasi Nasional. Jakarta; 1995.

13. Aini N, Wijonarko G, Sustriawan B. Sifat fisik, kimia, dan fungsional tepung jagung yang diproses melalui fermentasi. Agritech. 2016;36(2):160-9.

14. Rosiani FD. Pengaruh Substitusi Tepung Jagung Kuning Sebagai Sumber Vitamin A Terhadap Kualitas Organoleptik dan Kandungan Gizi Mie Kering. Food Sci Culin Educ J. 2013;2(2):47-55.

15. Rosidah R, Agustina T, Paramita O. Kualitas Organoleptik Roti Manis Subtitusi Tepung Jagung Kuning Dengan Metode Penepungan Berbeda. TEKNOBUGA J Teknol Busana dan Boga. 2019;7(1):46-52.

16. Musita N. Kajian Sifat Organoleptik Biskult Berbahan Baku Tepung Jagung Ternikstamalsasi Dan Terigu. J Din Penelit Ind. 2016;27(2):110-8. 